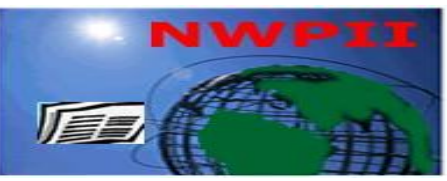

American Journal of Biomedical Sciences

ISSN: 1937-9080

nwpii.com/ajbms

\title{
Intake of Purine-rich Foods, Total Meat, Seafood and Dairy Products and Relationship to Serum of Uric Acid
}

\author{
MA Babiker \\ Department of Biochemistry, Alqunfudah University College, Umm Alqura University, Saudi Arabia \\ Corresponding Author \\ MA Babiker \\ Department of Biochemistry \\ Alqunfudah University College \\ Umm Alqura University \\ Saudi Arabia \\ Tel: +966544190526 \\ Fax: +966177323774 \\ E-mail: muhammed.wadaljad@ @otmail.com
}

Received: 26 September 2015; | Revised: 17 December 2015; $\mid$ Accepted: 15 February 2016

\begin{abstract}
Objective: To evaluate the relationship between serum uric acid levels and dietary factors in a nationally representative sample of healthy Sudanese men who were not taking medication for gout at the time of the study. Methods: Over twelve months period we followed and investigated the relationship between the intake of purine-rich foods, protein, and dairy products and status of uric acid management in 812 men who had no history of gout at base line, aged 30 years and older. Diet was assessed every month by means of a food-frequency questionnaire. Results: During one year of the study, we clearly documented that the multivariate relative risk of gout among men was found in the highest quintile for both meat and seafood intake, as compared to those in the lowest quintiles. At the other hand, it is possible that the intake of dairy products plays a role in reducing uric acid concentration and protecting against gout. Serum uric acid concentration is increased with increasing total meat or seafood intake and decreased with increasing dairy products intake. After adjusting for age, the serum uric acid level in the highest quintile group of total meat intake was higher by $0.58 \mathrm{mg} / \mathrm{dl}(95 \% \mathrm{CI} 0.39,0.77 ; \mathrm{P}=0.001$ for trend) than that in the lowest quintile. The corresponding difference for seafood was $0.41 \mathrm{mg} / \mathrm{dl}(95 \% \mathrm{CI} 0.19,0.63 ; \mathrm{P}=0.005$ for trend). and -0.46 $\mathrm{mg} / \mathrm{dl}(95 \%$ CI $-0.81,-0.10 ; \mathrm{P}=0.02$ for trend) for total dairy intake. Conclusion: These findings clearly suggest that higher amounts of meat and seafood consumption is associated with an increased risk of gout, whereas a higher level of dairy products consumption may decrease the risk of gout.
\end{abstract}

Key words: Uric acid; Seafood; Meat; Dairy products. 


\section{Introduction}

Gout is the most common form of inflammatory arthritis caused by a buildup of uric acid. Characterized by achy, swollen joints in the legs and feet, gout may have a painful condition that often affects men more than women. Gout may also be hereditary, but its exact cause is unknown. For years, researchers have found yet another reason to observe attentively what you eat. Apparently, the choices you make at the dinner table can affect your risk of developing gout. Recent evidence suggested that uric acid (UA), even so of crystal deposition, may play a direct pathogenic role in renal disease. Ubiquitous of UA is consequent of purine metabolism and was thought to have a beneficial role by acting as an antioxidant [1]. Even though the link between UA and impaired renal function is well known, it has not received much care, since hyperuricemia was considered simply a consequence of reduced glomerular filtration rate (GFR). Recent evidence, however, supports the view that UA may not be just an innocent bystander but may play an active role in the pathogenesis of renal disease [2,3]. Uric acid levels are affected by dietary factors, such as high levels of protein, sea food and by the breakdown of the body's cells. For years, physicians have been advising their patients with hyperuricemia to reduce frequent consumption of purine-rich foods such as animal protein, seafood and purinerich vegetables. This advice and causions based on evidence that suggests high purine intake increase levels of uric acid in the blood. And too high levels of uric acid crystals may form in and around joints, leading to gout. In study of Third National Health and Nutrition Examination Survey ( NHANES-III ), found that sUA increases with increasing consumption of meat, bear and seafood [4,5]. Prospective studies of Academy of Medical Sciences (2004) suggested that high protein intake leads to hyperuricemia and gout [ 6 ]. Similarly, in cities of eastern China, sUA levels were greater with bear than spirits, whereas wine consumption was not associated with hyperuricemia [ 7 ]. A recent study in Germany and the UK showed the same $1.4 \%$ prevalence of gout in both countries over the period 2000-05 [ 8 ]. On the other hand, several studies have suggested that there may be an inverse association between the consumption of dairy products and the serum uric acid level [9,10]. A study of over 2000 adults concluded that no association between purine-rich vegetables consumption and plasma urate [11]. In addition, a review of the lifestyle evidence reducing uric acid specifically mentions the benefits of increasing intake of purine-rich vegetables [12], and a number of other dietary factors might act on the same line, for example, vitamin C [13], coffee [14,15], dairy products $[5,16]$ and fruits [17].

\section{Materials and Methods}

A cohort of 636 volunteers, over 30 years old, were examined and investigated in this study. All investigated participants were normally healthy, they were not on any treatment for gout, hypertention, diabetes mellitus at the time of study, the study was conducted at khartoum city (SUDAN), between February 2014 and August 2015. Most of the participants are officers following sedentary lifestyle, some of them with free lance, and the rest are farmer. Follow-up questionnaires were provided, and the subjects were asked about the status of uric acid and hypertension. The questionnaire also included socio-demographic data in the form of age, gender, lifestyle and educational level. After a home interview, participants were invited and blood specimens were obtained. In addition, we excluded all donors who were undergoing treatment for gout or self-reported gout (18 donor). we performed our analyses among the remaining 618 participants. Serum uric acid was measured for all participants by oxidization to form allantoin and $\mathrm{H}_{2} \mathrm{O}_{2}$, using (hitachi model 912 multichannel autoanalyzer; tokyo, japan) instrument with ready to use boehringer Mannheim kits were used. values are reported in milligrams per deciliter (to convert to micromoles per liter, multiply by 59.48). 


\subsection{Dietary assessment}

Dietary assessment was based on data and information from a food frequency questionnaire, food frequency information was obtained by interview, during the frequent household visit and has been clearly shown to be a true and reliable procedure for assessing average consumption $[18,19]$. participants were asked how often they had eaten specific food items over the previous month. from these data, we calculated the average daily intake of each food item. the average daily intakes of each item were then combined to calculate the following composite food groups: total meat (beef, including hamburger, steaks ,meatloaf and roast beef ; and spare ribs; liver and other organ meats, including heart, kidney, tongue and sausage; all types of poultry, including baked or fried chicken nuggets, chicken salad ; seafood (fish, including fillets, tuna, fish sandwiches and fish sticks; shrimp, clams, oysters, crab ) ; dairy foods (milk; yogurt and frozen yogurt; ice cream, ice milk, and milkshakes; cheese of all types, including denmark, american, swiss, cheddar, cottage cheese, and local cheese made ).

\subsection{Collection of blood samples and isolation of plasma}

Venous blood specimens were taken from the participants in a sitting position using venoject vacuum containers between 8.00 and 9.00 am and collected in tubes containing heparin (final concentration up to $75 \mathrm{U} / \mathrm{ml}$ ). The blood centrifuged at $5000 \mathrm{rpm}$ for $10-15$ minutes by Heraeus tabletop Centrifuge Labofuge 400. two rotors. 4-fold swing-out rotor 8179. (model 400, Germany). The resulting plasma was kept on ice and the experiments were performed within a period not exceeding two hours.

For all tests required ( uric acid, total cholesterol, and creatinine ) enzymatic methods, and a Hitachi 912 autoanalyser (Hitachi, Tokyo, Japan) instrument with ready to use Boehringer Mannhiem kits were used. The instrument is checked, calibrated and controlled prerunning the samples.

\subsection{Statistical analysis}

Statistical analysis was performed using Statistical Package for Social Science (SPSS). Linear regression was used to evaluate relationships between food groups and serum uric acid level . The average daily intake for a food group or an individual food item was classified into quintiles of intake whenever necessary, and each quintile group of intake was compared with the lowest quintile group of intake. Multivariate models were adjusted for age, sex, BMI, use of diuretics, allopurinol, and uricosuric agents, selfreported hypertension and gout, serum creatinine level, total meats, seafood, and dairy foods. In the multivariate nutrient-density model for protein intake [20]. For all difference estimates, we calculated $95 \%$ confidence intervals (95\% CIs). All $P$ values are 2 -sided.The data for numerical values were expressed in mean \pm standard deviation (SD). Differences between each investigated quintile whenever in total meat, seafood or dairy product mean value and normal (quintile1) group were obtained, the results were consider statistically significant when the differences show equal or more than (SD).

\subsection{Calibration and quality control}

Uric acid and creatinine were standardized using a calibrator for automated systems (c.f.a.s). For total cholesterol (T.C) c.f.a.s. lipids is used. For plasma uric acid, creatinine and total cholesterol two levels of controls often assayed at least once a day, Precinorm U as low control, and Precipath $U$ as high control

\section{Results}

All of the investigated population are adults male, the mean age of the study participants was 44 years. The mean serum uric acid level for different food intakes was $5.25 \mathrm{mg} / \mathrm{dl}, 5.27$ $\mathrm{mg} / \mathrm{dl}$, and $5.26 \mathrm{mg} / \mathrm{dl}$ for each of total meat, seafood and dairy products respectively. The characteristics according to intake of purine-rich food groups and dairy foods are shown in Table 1.

Serum uric acid concentration increased with increasing of total meat ( Table 2 ) or seafood intake ( Table 3) and decreased with increasing dairy products intake ( Table 4 ). After adjusting 
for age, the serum uric acid level in the highest quintile group of total meat intake was higher by $0.59 \mathrm{mg} / \mathrm{dl}\left(95 \%\right.$ CI $0.39,0.77 ; P_{-} 0.001$ for trend) than that in the lowest quintile. The corresponding difference for seafood was 0.41 $\mathrm{mg} / \mathrm{dl}$ (95\% CI 0.19, 0.63; $P_{-} 0.005$ for trend). and $-0.46 \mathrm{mg} / \mathrm{dl}(95 \% \mathrm{CI}-0.81,-0.10 ; \mathrm{P}=0.02$ for trend) for total dairy intake. After adjusting for other variables, the differences between the extreme quintiles were languished but still significant $\left(P_{-} 0.05\right.$ for both comparisons $)$ (Table 2).

Table 1. Characteristics according to intake of purine-rich food groups and dairy foods

\begin{tabular}{|c|c|c|c|c|c|c|c|}
\hline Variable & $\begin{array}{l}\text { Daily intake, } \\
\text { serving/day }\end{array}$ & Age, year & $\begin{array}{l}\text { BMI, } \\
\mathrm{kg} / \mathrm{m}^{2}\end{array}$ & $\begin{array}{c}\text { Diuretic, } \\
\text { use \% }\end{array}$ & $\begin{array}{c}\text { Uric acid } \\
\text { drug use, \% }\end{array}$ & $\begin{array}{c}\text { Creatinine } \\
\text { (mg/dl) }\end{array}$ & $\begin{array}{c}\text { History } \\
\text { Hypertension \% }\end{array}$ \\
\hline \multicolumn{8}{|l|}{ Total meat } \\
\hline Quintile 1 & $<0.60$ & 44 & 28 & 2 & 1 & 0.9 & 12 \\
\hline Quintile 3 & $0.90-1.40$ & 43 & 27 & 1 & 1 & 1.0 & 11 \\
\hline Quintile 5 & $>2.00$ & 44 & 29 & 2 & 2 & 1.1 & 15 \\
\hline \multicolumn{8}{|l|}{ Seafood } \\
\hline Quintile 1 & $<0.06$ & 44 & 28 & 2 & 2 & 0.9 & 12 \\
\hline Quintile 3 & $0.13-0.16$ & 46 & 27 & 2 & 1 & 0.9 & 10 \\
\hline Quintile 5 & $>0.32$ & 44 & 26 & 2 & 2 & 1.1 & 11 \\
\hline \multicolumn{8}{|l|}{ Dairy food } \\
\hline Quintile 1 & $<0.06$ & 46 & 29 & 1 & 1 & 1.0 & 13 \\
\hline Quintile 3 & $1.10-1.50$ & 44 & 29 & 3 & 3 & 1.1 & 12 \\
\hline Quintile 5 & $>2.00$ & 45 & 28 & 3 & 2 & 1.1 & 11 \\
\hline
\end{tabular}

In the age-adjusted analysis for individual meat items, the differences in serum uric acid levels between the extreme quintiles of intake were $0.62 \mathrm{mg} / \mathrm{dl}(95 \%$ CI $0.47,0.74)$ for beef, $0.31 \mathrm{mg} / \mathrm{dl}(95 \%$ CI $0.20,0.41)$ for pork, and $0.52 \mathrm{mg} / \mathrm{dl}(95 \% \mathrm{CI} 0.36,0.68)$ for processed meats. These quantities were emaciated, but still significant, after adjustment of multivariate (Table 3). Same as in meat, for seafood items, higher intake of individual was associated with higher level of serum uric acid ( Table 3). For total dairy food intake and After adjusting for age, the serum uric acid level in the highest quintile group was lower than that in the lowest by $0.27 \mathrm{mg} / \mathrm{dl}\left(95 \%\right.$ CI $0.05,0.48 ; P_{-} 0.02$ for trend). After the covariates adjustment, the difference between the extreme quintiles remained considerable $(P-0.005$ for trend $)$ (Table 2). Those who consumed yogurt_one time per day had a lower serum uric acid concentration than did those who did not take (multivariate difference _0.26 [95\% CI _0.41, _0.12]; $P$ 0.001 for trend) (Table 3). Similarly, those who drank milk one time per day or at least once every other day had a lower uric acid concentration than did those who did not drink 
milk (multivariate difference -0.25 [95\% CI $-\quad 0.40,-0.09] ; P_{-} 0.001$ for trend).

Table 2. Serum uric acid in different quintiles of intake of total meat groups

\begin{tabular}{|c|c|c|c|c|c|c|c|}
\hline Variable & $\begin{array}{c}\text { No of } \\
\text { subjects }\end{array}$ & $\begin{array}{l}\text { Mean of } \\
\text { total } \\
\text { meat, } \\
\text { serving/ } \\
\text { day }\end{array}$ & $\begin{array}{l}\text { Mean } \pm \\
\text { SEM }\end{array}$ & $\begin{array}{l}\text { Age-adjusted } \\
\text { difference }\end{array}$ & $(95 \%$ CI ) & $\begin{array}{l}\text { Multivariate } \\
\text { Difference }\end{array}$ & $(95 \% \mathrm{CI})$ \\
\hline Quintile 1 & 40 & $<0.60$ & $5.01 \pm 0.06$ & 0.00 & Referent & 0.00 & Referent \\
\hline Quintile 2 & 44 & 0.80 & $5.09 \pm 0.07$ & 0.09 & $(-0.04,0.22)$ & -0.02 & $(-0.12,0.07)$ \\
\hline Quintile 3 & 38 & 1.15 & $5.18 \pm 0.06$ & 0.18 & $(0.07,0.28)$ & 0.04 & $(-0.05,0.14)$ \\
\hline Quintile 4 & 39 & 1.50 & $5.36 \pm 0.10$ & 0.36 & $(0.23,0.48)$ & 0,05 & $(-0.05,0.16)$ \\
\hline Quintile 5 & 41 & $>2.00$ & $5.59 \pm 0.12$ & 0.58 & $(0.39,0.77)$ & 0,13 & $(0.02,0.25)$ \\
\hline $\mathrm{P} /$ trend & & & & $>0.001$ & & 0.02 & \\
\hline $\begin{array}{c}\text { Difference } \\
\text { per unit } \\
\text { increase }\end{array}$ & & & & 0.27 & $(0.17,0.37)$ & 0.08 & $(0.02,0.13)$ \\
\hline
\end{tabular}

In the age-adjusted analysis for individual meat items, the differences in serum uric acid levels between the extreme quintiles of intake were $0.62 \mathrm{mg} / \mathrm{dl}(95 \%$ CI $0.47,0.74)$ for beef, $0.31 \mathrm{mg} / \mathrm{dl}(95 \%$ CI $0.20,0.41)$ for pork, and $0.52 \mathrm{mg} / \mathrm{dl}(95 \%$ CI $0.36,0.68)$ for processed meats. These quantities were emaciated, but still significant, after adjustment of multivariate (Table 3). Same as in meat, for seafood items, higher intake of individual was associated with higher level of serum uric acid ( Table 3). For total dairy food intake and After adjusting for age, the serum uric acid level in the highest quintile group was lower than that in the lowest by $0.27 \mathrm{mg} / \mathrm{dl}\left(95 \%\right.$ CI $0.05,0.48 ; P_{-} 0.02$ for trend). After the covariates adjustment, the difference between the extreme quintiles remained considerable $\left(P P_{-} 0.005\right.$ for trend) (Table 2). Those who consumed yogurt_one time per day had a lower serum uric acid concentration than did those who did not take (multivariate difference _0.26 [95\% CI _0.41, _0.12]; $P$ 0.001 for trend) (Table 3). Similarly, those who drank milk one time per day or at least once 
every other day had a lower uric acid milk (multivariate difference -0.25 [95\% CI concentration than did those who did not drink $0.40,-0.09] ; P_{-} 0.001$ for trend).

Table 2. Serum Uric Acid in Different Quintiles of Intake of Total Meat Groups

\begin{tabular}{|c|c|c|c|c|c|c|c|}
\hline Variable & $\begin{array}{c}\text { No of } \\
\text { subjects }\end{array}$ & $\begin{array}{c}\text { Mean of } \\
\text { total } \\
\text { meat, } \\
\text { serving/ } \\
\text { day }\end{array}$ & $\begin{array}{l}\text { Mean } \pm \\
\text { SEM }\end{array}$ & $\begin{array}{l}\text { Age-adjusted } \\
\text { difference }\end{array}$ & (95\% CI ) & $\begin{array}{l}\text { Multivariate } \\
\text { Difference }\end{array}$ & $(95 \% \mathrm{CI})$ \\
\hline Quintile 1 & 40 & $<0.60$ & $5.01 \pm 0.06$ & 0.00 & Referent & 0.00 & Referent \\
\hline Quintile 2 & 44 & 0.80 & $5.09 \pm 0.07$ & 0.09 & $(-0.04,0.22)$ & -0.02 & $(-0.12,0.07)$ \\
\hline Quintile 3 & 38 & 1.15 & $5.18 \pm 0.06$ & 0.18 & $(0.07,0.28)$ & 0.04 & $(-0.05,0.14)$ \\
\hline Quintile 4 & 39 & 1.50 & $5.36 \pm 0.10$ & 0.36 & $(0.23,0.48)$ & 0,05 & $(-0.05,0.16)$ \\
\hline Quintile 5 & 41 & $>2.00$ & $5.59 \pm 0.12$ & 0.58 & $(0.39,0.77)$ & 0,13 & $(0.02,0.25)$ \\
\hline $\mathrm{P} /$ trend & & & & $>0.001$ & & 0.02 & \\
\hline $\begin{array}{l}\text { Difference } \\
\text { per unit } \\
\text { increase }\end{array}$ & & & & 0.27 & $(0.17,0.37)$ & 0.08 & $(0.02,0.13)$ \\
\hline
\end{tabular}

\section{DISCUSSION}

In this representative sample of adults male, the results found that serum uric acid level was significantly increased with increasing meat and seafood consumption. Whereas, we registered a significant inverse association with dairy products consumption. These associations were independent of the other risk factors for hyperuricemia, such as age, sex, BMI, serum creatinine level, hypertension, alcohol use, and diuretic use. The current study findings indicate that the intake of meat and seafood in amounts obviously show that the nationwide consumption increases serum levels of uric acid. Despite it is not easily to predict and estimate whether a commonly consumed food actually affects the serum uric acid concentration, our study directly linked common foods and serum uric acid levels and provides the related information. Previously, Health Professionals Follow-up Study reported an increase in risk with meat consumption [21], and 
that is in agreement with our findings. In addition, it was reported that higher seafood intake was a risk, and higher dairy products intake has an inverse association with uric acid [21,22], which is consistent with our results. Furthermore, it was reported that higher seafood intake was shown prospectively to reduce risk of gout [23], which we did not find.

As it is obviously shown that in this study there was positive stepwise association between meat and seafood consumption and uric acid levels, we registered The lowest values of uric acid with lowest quintile group of consumption, then started to elevates with increasing of consumption of meat and seafood through all quintiles, but significant only in highest quintile of consumption, the adjusted values of uric acid were on average of $0.58 \mathrm{mg} / \mathrm{dl}$ (95\% CI 0.39 , $0.77 ; P_{-} 0.001$ for trend) higher than that in the lowest quintile. Correspondingly the difference for seafood was $0.41 \mathrm{mg} / \mathrm{dl}(95 \%$ CI $0.19,0.63 ; P$ - 0.005 for trend). And lowest by $-0.46 \mathrm{mg} / \mathrm{dl}$ (95\% CI $-0.81,-0.10 ; \mathrm{P}=0.02$ for trend) for total dairy products, which was quite significantly low.

Table 3. Serum Uric Acid in Different Quintiles of Intake of Seafood Groups.

\begin{tabular}{|c|c|c|c|c|c|c|c|}
\hline Variable & $\begin{array}{l}\text { No of } \\
\text { subjects }\end{array}$ & $\begin{array}{l}\text { seafood, } \\
\text { serving/ day }\end{array}$ & $\begin{array}{l}\text { Mean } \pm \\
\text { SEM }\end{array}$ & $\begin{array}{l}\text { Age- } \\
\text { adjusted } \\
\text { difference }\end{array}$ & $(95 \% \mathrm{CI})$ & $\begin{array}{l}\text { Multivariate } \\
\text { Difference }\end{array}$ & $(95 \% \mathrm{CI})$ \\
\hline Quintile 1 & 34 & $<0.05$ & $5.09 \pm 0.05$ & 0.00 & Referent & 0.00 & Referent \\
\hline Quintile 2 & 46 & $0.06-0.12$ & $5.12 \pm 0.04$ & 0.09 & $(-0.04,0.21)$ & -0.02 & $(-0.12,0.07)$ \\
\hline Quintile 3 & 38 & $0.13-0.19$ & $5.29 \pm 0.06$ & 0.14 & $(0.07,0.21)$ & 0.05 & $(-0.05,0.15)$ \\
\hline Quintile 4 & 38 & $0.20-0.32$ & $5.36 \pm 0.06$ & 0.29 & $(0.15,0.42)$ & 0,06 & $(-0.04,0.16)$ \\
\hline Quintile 5 & 42 & $>0.32$ & $5.50 \pm 0.05$ & 0.41 & $(0.19,0.63)$ & 0,14 & $(0.02,0.25)$ \\
\hline $\mathrm{P} /$ trend & & & & $<0.003$ & & 0.04 & \\
\hline $\begin{array}{l}\text { Difference } \\
\text { per Unit } \\
\text { increase }\end{array}$ & & & & 0.24 & $(0.15,0.34)$ & 0.14 & $(0.05,0.23)$ \\
\hline
\end{tabular}


Table 4. Serum Uric Acid in Different Quintiles of Intake of Total Dairy Product Groups

\begin{tabular}{|c|c|c|c|c|c|c|c|}
\hline Variable & $\begin{array}{l}\text { No of } \\
\text { subjects }\end{array}$ & $\begin{array}{l}\text { Dairy } \\
\text { products, } \\
\text { serving/ day }\end{array}$ & $\begin{array}{l}\text { Mean } \pm \\
\text { SEM }\end{array}$ & $\begin{array}{l}\text { Age- } \\
\text { adjusted } \\
\text { difference }\end{array}$ & $(95 \%$ CI ) & $\begin{array}{l}\text { Multivariate } \\
\text { Difference }\end{array}$ & $(95 \%$ CI $)$ \\
\hline Quintile 1 & 50 & $<0.06$ & $5.46 \pm 0.04$ & 0.00 & Referent & 0.00 & Referent \\
\hline Quintile 2 & 48 & $0.6-1.00$ & $5.34 \pm 0.04$ & -0.08 & $(-0.20,0.04)$ & 0.04 & $(-0.12,0.04)$ \\
\hline Quintile 3 & 40 & $1.1-1.5$ & $5.34 \pm 0.06$ & . -0.07 & $(-0.19,0.05)$ & -0.04 & $(-0.13,0.05)$ \\
\hline Quintile 4 & 38 & $1.6-2.00$ & $5.16 \pm 0.06$ & 0.14 & $(-0.31,0.03)$ & $-0,08$ & $(-0.22,0.06)$ \\
\hline Quintile 5 & 42 & $>2.00$ & $5.00 \pm 0.05$ & -0.46 & $(-0.81,-0.10)$ & $-0,13$ & $(-0.35,0.09)$ \\
\hline $\mathrm{P} /$ trend & & & & 0.02 & & 0.004 & \\
\hline $\begin{array}{l}\text { Difference } \\
\text { per Unit } \\
\text { increase }\end{array}$ & & & & -0.07 & $(-0.10,-0.04)$ & -0.04 & $(-0.10,0.02)$ \\
\hline
\end{tabular}

\section{Conclusion}

In this study, experimental evidence indicates that higher amounts of meat and seafood consumption is associated with an increased risk of gout, whereas a higher level of dairy products consumption is inversely associated with the risk of gout.

\section{References}

1. Ames BN, Cathcart R, Schwiers E, Hochstein P: Uric acid provides an antioxidant defense in humans against oxidant- and radical-caused aging and cancer: a hypothesis. Proc Natl Acad Sci USA 1981, 78: 6858 - 6862. DOI: 10.1073/pnas.78.11.6858

2. Kanellis J, Feig DI, Johnson RJ: Does asymptomatic hyperuricaemia contribute to the development of renal and cardiovascular disease? An old controversy renewed. 
Nephrology (Carlton) 2004, 9:394-399. DOI: 10.1111/j.1440-1797.2004.00336.x

3. Feig DI, Rodriguez-Iturbe B, Nakagawa T, Johnson RJ: Nephron number, uric acid, and renal microvascular disease in the pathogenesis of essential hypertension. Hypertension 2006, 48:25-26. DOI: 10.1161/01.HYP.0000223447.53155.d5

4.. Choi HK, Curhan G. Beer, liquor, and wine consumption and serum uric acid level: the Third National Health and Nutrition Examination Survey . Arthritis Rheum 2004;51:1023-9. DOI: 10.1002/art.20821

5.. Choi HK, Liu S, Curhan G. Intake of purinerich foods, protein, and dairy products and relationship to serum levels of uric acid: the Third National Health and Nutrition Examination Survey . Arthritis Rheum 2005;52:283-9. DOI: 10.1002/art.20761

6. Academy of Medical Sciences. Calling time: the nation's drinking as a major health issue. London: Academy of Medical Sciences; 2004.

7.. Miao Z, Li C, Chen Y, et al. Dietary and lifestyle changes associated with high prevalence of hyperuricemia and gout in the Shandong coastal cities of Eastern China. J Rheumatol 2008;35:1859-64.

8 . Annemans L, Spaepen E, Gaskin M, et al . Gout in the UK and Germany: prevalence, comorbidities and management in general practice 2000-2005. Ann Rheum Dis 2008;67:960-6. DOI: $\underline{10.1136 / \operatorname{ard} .2007 .076232}$

9. Loenen HM, Eshuis H, Lowik MR, et al. Serum uric acid correlates in elderly men and women with special reference to body composition and dietary intake (Dutch Nutrition Surveillance System). J Clin Epidemiol 1990;43:1297-1303. DOI: 10.1016/0895-4356(90)90095-7

10. Garrel DR, Verdy M, PetitClerc C, Martin C, Brule D, Hamet P. Milk- and soy-protein ingestion: acute effect on serum uric acid concentration. Am J Clin Nutr 1991;53:665669.

11. Zgaga L, Theodoratou E, Kyle J, Farrington SM, Agakov F, Tenesa A, Walker M, McNeill G, Wright AF, Rudan I, Dunlop MG,
Campbell $\mathrm{H}$. The association of dietary intake of purine-rich vegetables, sugarsweetened beverages and dairy with plasma urate, in a cross-sectional study. Plos One; 2012; 7 (6): e38123 DOI: 10.1371/journal.pone. 0038123

12. Choi HK . A prescription for lifestyle change in patients with hyperuricemia and gout. Current Opinion in Rheumatology 2010 ; 22: 165-172.

DOI: 10.1097/BOR.0b013e328335ef38

13. Gao X, Curhan G, Forman JP, Ascherio A, Choi HK. Vitamin $C$ intake and serum uric acid concentration in men. $\mathrm{J}$ Rheumatol 2008;35:1853-8.

14. Choi HK, Curhan G. Coffee, tea, and caffeine consumption and serum uric acid level: the Third National Health and Nutrition Examination Survey. Arthritis Rheum 2007;57:816-21. DOI: 10.1002/art.22762

15. Choi HK, Willett W, Curhan G. Coffee consumption and risk of incident gout in men: a prospective study. Arthritis Rheum 2007;56:2049-55. DOI: 10.1002/art.22712

16. Choi HK, Atkinson K, Karlson EW, Willett W, Curhan G. Purine-rich foods, dairy and protein intake, and the risk of gout in men. $\mathrm{N}$ Engl J Med 2004;350:1093-103. DOI: $\underline{\text { 10.1056/NEJMoa035700 }}$

17. Lyu LC, Hsu CY, Yeh CY, Lee MS, Huang $\mathrm{SH}$, Chen CL. A case-control study of the association of diet and obesity with gout in Taiwan. American Journal of Clinical Nutrition 2003; 78: 690-701.

18. Hu FB, Rimm E, Smith-Warner SA, Feskanich D, Stampfer MJ, Ascherio A, et al. Reproducibility and validity of dietary patterns assessed with a food-frequency questionnaire. Am J Clin Nutr 1999; 69:2439.

19. Feskanich D, Rimm EB, Giovannucci EL, Colditz GA, Stampfer MJ, Litin LB, et al. Reproducibility and validity of food intake measurements from a semiquantitative food frequency questionnaire. J Am Diet Assoc 1993;93:790-6. DOI: 10.1016/00028223(93)91754-E

20 . Willett W. Nutritional epidemiology. 2nd ed. Oxford: Oxford University Press; 1998. DOI: 
$\underline{\text { 10.1093/acprof:oso/9780195122978.001.000 }}$ $\underline{1}$

21. Choi HK, Willett WC, Stampfer MJ, Rimm E, Hu FB. Dairy consumption and risk of type 2 diabetes mellitus in men: a prospective study. Arch Intern Med 2005;165:997-1003. DOI: 10.1001/archinte.165.9.997

22 . Choi HK, Atkinson K, Karlson EW, Willett W, Curhan G. Purine-rich foods, dairy and protein intake, and the risk of gout in men. $\mathrm{N}$
Engl J Med 2004;350:1093-103. DOI: 10.1056/NEJMoa035700

23 . Paul $\mathrm{T}$ Williams Effects of diet, physical activity and performance, and body weight on incident gout in ostensibly healthy, vigorously active men. Am J Clin Nutr. 2008 May; 87(5): 1480-1487. 